\title{
Конференции
}

ГАМАН-ГОЛУТВИНА Оксана Викторовна - доктор политических наук, профессор; заведующий кафедрой сравнительной политологии Московского государственного института международных отношений (университет) МИД РФ [МГИМО(У) МИД РФ] (119454, Россия, г. Москва, nр-кт Вернадского, 76, корп. B; оgатап@таil.ru); президент Российской ассоциации политической науки; илен Общественной палаты РФ, председатель ФУМО «Политические науки и регионоведение»; председатель Экспертного совета РФФИ

СМОРГУНОВ Леонид Владимирович - доктор философских наук, профессор, заведующий кафедрой политического управления Санкт-Петербургского государственного университета (191124, Россия, г. Санкт-Петербург, ул. Смольного, 1/3, под. 7; lvsmorgunov@gmail.com); вице-президент, председатель Научного совета Российской ассоциации политическойф науки

ТИМОФЕЕВА Лидия Николаевна - доктор политических наук, профессор кафедры политологии и политического управления Института общественных наук Российской академии народного хозяйства и государственной службы при Президенте РФ (119606, Россия, г. Москва, nр-кт Вернадского, 84; timofeeva-lidiya@inbox.ru), вице-президент, председатель правления Российской ассоциации политической науки

\section{РОССИЯ В УСЛОВИЯХ МИРОВОЙ КОНКУРЕНЦИИ: ПУТИ РАЗВИТИЯ}

\begin{abstract}
Аннотация. В статье речь идет о повестке дня и основном содержании VIII Всероссийского конгресса политологов «Политика развития, государство и мировой порядок», который прошел 6-8 декабря в Москве. Он вызвал большой интерес у политологической общественности и массмедиа. В нем участвовали более 1200 политологов и политиков из России и из 36 стран мира (Великобритания, США, Франция, Германия, Венгрия, Израиль, Иран, Испания, Италия, Швеция, Норвегия, Швейцария, Армения, Казахстан, Польша, Украина и др.). Были представлены крупнейшие международные профессиональные ассоциации - МАПН и Европейский консорциум политических исследований, а также национальные ассоциации ряда стран. Пленарные заседания прошли в МГИМО МИД РФ и в Финансовом университете при Правительстве РФ. На более чем 140 заседаниях обсуждались актуальные вопросы внутренней и международной политики, теоретические проблемы современной модели развития, роль государства и структуры нового мирового порядка.
\end{abstract}

Ключевые слова: политика развития, государство, мировой порядок, глобальная конкуренция, инклюзивное развитие, национальная стратегия экономического роста

$6-8$

В декабря 2018г. в Москве с большимуспехомпрошел VIII Всероссийский конгресс политологов «Политика развития, государство и мировой порядок». В нем участвовали более 1200 политологов и политиков из России и 36 стран мира (Великобритания, США, Франция, Германия, Венгрия, Израиль, Иран, Испания, Италия, Швеция, Норвегия, Швейцария, Армения, Казахстан, Польша, Украина и др.). Были представлены крупнейшие международные профессиональные ассоциации - МАПН и Европейский консорциум политических исследований, а также национальные ассоциации ряда стран. Пленарные заседания прошли в МГИМО МИД РФ и в Финансовом университете при Правительстве РФ. На более чем 100 заседаниях обсуждались актуальные вопросы внутренней и международной политики, теоретические проблемы современной модели развития, роль государства и структуры нового мирового порядка.

Конгресс приветствовали представители Федерального собрания РФ, Государственной думы РФ, Администрации Президента РФ, Министерства образования и науки РФ, Международной ассоциации политической науки, Европейского консорциума политических исследований, национальных ассоциаций политической науки ряда стран, Пагуошского движения ученых. 
Слова приветствия были переданы от председателя Совета Федерации ФС РФ В.И. Матвиенко, помощника президента РФ А.А. Фурсенко, министра иностранных дел РФ C.B. Лаврова. Первый заместитель руководителя Администрации Президента РФ С.В. Кириенко в своем приветствии Конгрессу отметил: «Программа форума отражает высокий уровень развития российской политологии, сложившееся и уважаемое профессиональное сообщество - неотъемлемая и передовая часть мировой науки... Сегодня перед политологами стоят масштабные задачи, мы живем в стремительно меняющуюся эпоху, и успех в мировой конкуренции как никогда зависит от экспертизы и понимания общественных процессов. Именно в социальных науках важно держать руку на пульсе общественной жизни, это создает условия для качественной экспертизы и прогно3ов».

На пленарных заседаниях выступили известные ученые и политики. С докладом выступил ректор МГИМО МИД РФ академик РАН A.B. Торкунов, который подчеркнул значение экспертной роли политологического сообщества, роль науки как конкурентного фактора, функции факультетов политологии; он остановился на исчерпаемости транзитологической парадигмы исследования современных процессов, простого прикладного анализа международных ситуаций и подчеркнул значение мирового комплексного регионоведения; особое значение, подчеркнул докладчик, в современном мире имеет управленческая наука и практика; он выделил три основных направления развития политологии: компаративистику, освоение всей (в т.ч. незападной) политологии, практикоориентированную подготовку политологов. В сообщении заместителя председателя Совета Федерации ФС РФ И.М. Умаханова содержалось приветствие к участникам конгресса, подчеркивалась роль политической науки для практики; он зачитал приветствие председателя Федерального собрания В.И. Матвиенко. Секретарь Общественной палаты РФ В.A. Фадеев в своем выступлении подчеркнул ряд вопросов, которые являются значимыми для их разработки политологами: это проблемы демократии, социального государства и экологии. Академик РАН $\boldsymbol{A}$. $\boldsymbol{A}$. Дынкин в своем докладе говорил о вызовах современного развития - экзистенциальных, социально-политических и трансформационных; он подчеркнул значение нематериальных ресурсов развития в противоположность ориентации в развитии на модель потребления. Директор института Европы РАН член-корреспондент РАН $\boldsymbol{A}$.A. Громыко охарактеризовал основные тенденции современных мировых отношений и подчеркнул неоднозначность формирующегося мирового порядка. Президент МАПН М. Кноер (Германия) приветствовала участников конгресса от имени Международной ассоциации политической науки и обратила внимание на проблемы академической свободы и роль международного сотрудничества политологов. Председатель исполкома ЕКПИ $\boldsymbol{K}$. Дешауэр (Бельгия) говорил о роли консорциума в развитии европейской политической науки и пожелал участникам конгресса успехов в обсуждении актуальных вопросов развития. На пленарном заседании в МГИМО также выступили директор ИМЭМО им. Е.М. Примакова член-корреспондент РАН Ф.Г. Войтоловский, научный руководитель Института США и Канады академик РАН C.M. Рогов, директор Департамента государственной политики в сфере высшего образования и молодежной политики Министерства науки и образования РФ А.И. Рожков и др.

Президент РАПН, доктор политических наук, профессор, заведующий кафедрой сравнительной политологии МГИМО МИД России, член Общественной палаты РФ, председатель ФУМО «Политические науки и регионоведение» O.B. Гаман-Голутвина приветствовала участников конгресса и сделала доклад об основных направлениях развития современной политической науки, под- 
черкнув ее значение для политической практики и общего понимания стратегии и основных направлений развития общества.

На 2-м пленарном заседании в Финансовом университете при Правительстве РФ выступили ректор Финансового университета при Правительстве РФ M.A. Эскиндаров, заместитель председателя Государственной думы ФС РФ П.О. Толстой, советник президента РФ академик РАН С.Ю. Глазьев, первый заместитель директора ИМЭМО им. Е.М. Примакова РАН академик РАН Н.И. Иванова, член Совета Федерации Федерального собрания РФ, российский политик и ученый-историк, политолог В.П. Лукин, директор Федерального научно-исследовательского социологического центра РАН академик РАН M.K. Горшков, первый проректор Финансового университета при Правительстве РФ кандидат политических наук $\boldsymbol{K}$. B. Cимонов, професcop Стэнфордского университета $\boldsymbol{C m}$. Краснер (США), председатель исполнительного комитета Пагуошского движения ученых $\mathbf{C m}$. Миллер (США) и др. В докладах и выступлениях анализировались современные тенденции и факторы экономического и социального развития, основные модели, объясняющие современные факторы экономического роста, роль национальных стратегий развития и т.д.

На более 100 секционных заседаниях рассматривались различные аспекты политики развития и политической науки. Основная тема конгресса рассматривалась на 28 заседаниях. Первое заседание по основной теме конгресса включало в себя доклады, раскрывающие различные аспекты современных концепций общественного развития и их трансформацию в политические проекты. Подчеркивалось значение идеологии и мифологии, раскрывалось значение глобального проектирования, были выделены особенности восприятия времени в условиях динамических изменений. Ряд докладов были посвящены конкретным теориям и политическим проектам. Специальное секционное заседание было посвящено критическому анализу доминирующей идеологии политических процессов в современном мире - неолиберализму. Основная идея секции - умаление значения политики в неолиберализме как в инклюзивной сфере поиска общественных ценностей и решений. Анализировались кризисные черты развития в условиях неолиберализма и конкретные формы их выражения. Императивом современного инклюзивного развития, как подчеркивалось на секциях, является противостояние бедности и несправедливому неравенству. На особой секции были представлены доклады, раскрывающие содержание политики, направленной против бедности и неравенства, а также институциональные формы, обеспечивающие ее эффективность. Обсуждались проблемы соотношения демократии и политики противодействия неравенству и бедности, роли гражданского общества в этой политике. Анализировалась соответствующая политика в России. Важным аспектом политологического анализа развития является изучение взаимодействия политических режимов и соответствующей политики. На данной секции были представлены доклады теоретического и эмпирического уровня, в которых рассматривались национальные и субнациональные политические режимы в связи с различными направлениями политики развития. На заседании секции, посвященной культурному многообразию, на различных примерах социокультурного многообразия в истории и в различных странах проводилась идея связи социокультурного плюрализма с политикой развития. Особое внимание здесь уделялось проблемам представления социокультурного многообразия в сознании молодежи. Рассматривались проблемы многообразия политики в глобальном мире. Заседание специальной секции было посвящено раскрытию соотношения теории и практики фор- 
мирования мирового политического порядка. Рассматривались темы международной политической реальности, соотношения международного права и реальной политики, полицентричности современных мировых отношений. Часть докладов раскрывали российскую проблематику, связанную с внешней политикой государства. Заседание секции по современному государству включало в себя 4 доклада о различных аспектах соотношения стабилизации и развития. В докладах подчеркивались не только корреляционная связь между ними, но и проблемы детерминации, возникающие в условиях политики развития. Критическому анализу подверглась метафора «революционные волны». Представлен конкретный пример развития в условиях борьбы за независимость сообщества в современном государстве. На заседании по цифровой революции были представлены доклады, раскрывающие новые параметры влияния ИКТ на современную политику. Центром анализа выступала цифровая революция и ее неоднозначное воздействие на политические процессы. С одной стороны, новая цифровая реальность способствует «умному» развитию, с другой - возникают проблемы и риски коммуникации и новая цензура. Проблематика специального заседания секции была связана с вопросом особенностей национальной стратегии развития и экономического роста в России. В докладах были представлены материалы исследований, касающихся как перспективных условий выработки политики развития, так и сдерживающих факторов. Внимание уделялось интеллектуальным условиям выработки соответствующей политики в российском политическом пространстве. Национальная политика развития неотделима от участия страны в мировых процессах. На секции «Вызовы и перспективы мирового позиционирования России» были представлены доклады, относящиеся к раскрытию перспектив мирового позиционирования России. Рассматривались различные факторы такого позиционирования, такие как национальный брендинг, образ будущего, идентичность. Представлены материалы по некоторым конкретным стратегиям, например по Арктическому вектору. Часть докладов были посвящены культурным аспектам позиционирования. Заседание секции по основной теме конгресса было посвящено обсуждению места и роли Китая в современном мире и его влияния на мировые процессы развития. Обсуждение вопросов определялось в представленных докладах как в общей форме (внутренняя и внешняя политика КНР), так и в аспекте двух- и многосторонних отношений Китая и других стран. Изменяющейся роли США в современном мире посвящены доклады особой секции. В них освещались вопросы внешней политики Соединенных Штатов и ее особенности применительно к российско-американским отношениям. Особое внимание уделялось глобалистским внешнеполитическим стратегиям и теориям. В рамках секции «Восток как пространство мировой политической конкуренции» рассматривалось современное мировое развитие сквозь призму исторического процесса стран Востока. Проблематика секции была направлена на раскрытие некоторых проблем, связанных с отношением стран Востока и мировой политической конкуренцией. Представлена тематика энергетической политики, внутринациональных тенденций в некоторых странах, российской внешнеполитической стратегии по отношению к Ближнему Востоку.

Заседания по основным направлениям политической науки включали в себя доклады, посвященные различным темам политологических исследований, которые закрепляют соответствующую отрасль в рамках развития политологии в России. Цель этих заседаний - подтвердить наличие соответствующих научных суботраслей и показать их вклад в тематику конгресса. Данные заседания продемонстрировали, что политика развития, государство и мировой 
порядок являются сложными объектами исследований, предполагающими разнообразные теоретические, методологические и тематические направления. В целом направления политической науки здесь были представлены секциями по теории, философии и методологии политической науки, институциональным исследованиям политики, публичной политике и управлению, мировой политике и международным отношениям, социокультурным и интеллектуальным процессам политики, политической коммуникативистике и новым информационным технологиям.

На конгрессе прошли заседания 22 исследовательских комитетов РАПН, специальные тематические заседания и специальные заседания, посвященные обсуждению вопросов журналов. В рамках конгресса состоялись заседания Экспертного совета ВАКа, секций ФУМО по группе специальностей 41.00.00 «Политические науки и регионоведение», президиума Академии политической науки. Прошли презентации журналов, книг, исследовательских проектов.

V Форум молодых политологов «Развитие государства и общества: идеи, субъекты, институты и практики», традиционно проходящий в рамках конгресса РАПН, собрал более 150 участников.

В целом VIII Всероссийский конгресс политологов «Политика развития, государство и мировой порядок» явился значимым событием в научной жизни страны и продемонстрировал высокий потенциал политической науки в познании и политической практике.

GAMAN-GOlUTVINA Oksana Viktorovna, Dr.Sci. (Pol.Sci.), Professor, Head of the Chair of Comparative Politics, Moscow State Institute of International Relations, University of the Ministry for Foreign Affairs of Russia (76 Vernadskogo Ave, Moscow, Russia, 119454; ogaman@mail.ru); President of the Russian Political Science Association; member of the Public Chamber of the Russian Federation; Chairman of the Federal Educational and Methodical Association (UMO) «Political Sciences and Regional Studies», Chairman of the Expert Council of RFBR

SMORGUNOV Leonid Vladimirovich, Dr.Sci. (Philos.), Professor, Head of the Chair of Political Management, St. Petersburg State University (7th entr, 1/3 Smolnogo St, St. Petersburg, Russia, 191124; lvsmorgunov@gmail.com), Vice President, Chairman of Scientific Council of the Russian Political Science Association

TIMOFEEVA Lidiya Nikolaevna, Dr.Sci. (Pol.Sci.), Professor of the Chair of Political Science and Political Management, Presidential Academy of National Economy and Public Administration (RANEPA) (84 Vernadskogo Ave, Moscow, Russia, 119606; timofeeva-lidiya@inbox.ru); Vice President, Chairwoman of the Board of the Russian Political Science Association

\section{RUSSIA IN TERMS OF GLOBAL COMPETITION: WAYS OF DEVELOPMENT}

\footnotetext{
Abstract. In the article, the authors show the agenda and content of the Eighth All-Russian Congress of Political Scientists "Development Policy, State and World Order», which took place in December 6-8, 2018 in Moscow. The Congress aroused great interest among the political science community and the media. More than 1,200 political scientists and politicians from Russia and 36 foreign countries (UK, USA, France, Germany, Hungary, Israel, Iran, Spain, Italy, Sweden, Norway, Switzerland, Armenia, Kazakhstan, Poland, Ukraine, etc.) attended it. The largest international professional associations - the IPSA and the ECPR, as well as national associations of a number of countries were represented. Plenary sessions were held at MGIMO and the Financial University under the Government of the Russian Federation. Topical issues of domestic and international politics, theoretical problems of the modern model of development, the role of the state and the structure of the new world order were discussed at more than 140 panels.

Keywords: development policy, state, world order, global competition, inclusive development, national strategy for economic growth
} 